\title{
Michal Jasiński*
}

Szkoła Główna Handlowa w Warszawie

\section{MODELE ROZWOJU GOSPODARCZEGO A POZIOM ROZWOJU SPOKECZNEGO I ZAMOŻNOŚCI W MAŁYCH PAŃSTWACH WYSPIARSKICH NA ŚWIECIE}

\begin{abstract}
Streszczenie
Przedmiotem artykułu jest analiza modeli rozwoju i poziomu rozwoju społeczno-ekonomicznego w 29 małych państwach wyspiarskich (SIDS). Modele rozwoju wyznaczono w oparciu o klasyfikacje: MIRAB/SITE/PROFIT, jak i dane wpływów z eksportu towarowego, turystyki zagranicznej, pomocy rozwojowej i przekazów z zagranicy (w odsetkach) w Produkcie Krajowym Brutto (PKB). Poziom rozwoju społeczno-ekonomicznego wyznaczono w oparciu o wskaźniki rozwoju społecznego (HDI) oraz zamożności (dochód narodowy na osobę). Przeprowadzone analizy wykazały, że gospodarki, które miały cechy modelu PROFIT, PROFIT/SITE lub SITE - charakteryzowały się wysokim poziomem rozwoju. W przypadku modelu MIRAB oraz MIRAB/PROFIT w większości przypadków rozwój był bardzo niski. W modelu hybrydowym MIRAB/SITE występującym w 4 państwach - w 2 przypadkach poziom rozwoju był wyższy od przeciętnego na świecie. Stwierdzono ponadto, że rozwój sektora turystycznego (model SITE) w 6 przypadkach spowodował znaczne przyspieszenie rozwoju i dynamiczne „doganianie” najbardziej rozwiniętych małych gospodarek wyspiarskich. Potwierdziło to wcześniejsze badania autora (Jasiński,
\end{abstract}

\footnotetext{
*Adres e-mail: michal.jasinski@sgh.waw.pl.
} 
2009, 2010), w tym szczególnie tezę, że rozwój sektora turystycznego (model SITE) stanowi niezbędną fazę pobudzenia rozwoju społeczno-gospodarczego w SIDS.

Słowa kluczowe: MIRAB, SITE, PROFIT, rozwój społeczny, małe państwa wyspiarskie

\section{Wprowadzenie}

Małe państwa/terytoria wyspiarskie (Small Island Developing States - SIDS) stawią specyficzną grupę, których gospodarka charakteryzuje się specyficzną „kruchością"1, wynikającą z cech geograficznych (małe rozmiary, ograniczone zasoby naturalne, izolacja, klęski żywiołowe). Cechy te determinują wąską specjalizację i marginalne znaczenie w handlu międzynarodowym. Gospodarki te m.in. nie są w stanie wykorzystać efektu skali, uzależnione są od importu, jak również charakteryzują się niskim stopniem wykorzystania zasobów pracy, kulturową dominacją Północy, wysokimi kosztami transportu, infrastruktury i administracji oraz podatnością na działalność przestępczą (pranie brudnych pieniędzy, narkotyki, korupcja). Grupa ta, pomimo pozornie wspólnych cech, jest różnorodna pod względem uwarunkowań przyrodniczych, historycznych i społecznych - w konsekwencji silnie rozwarstwiona pod względem poziomu rozwoju społeczno-gospodarczego.

W literaturze przedmiotu niejednokrotnie dokonywano klasyfikacji SIDS uwzględniając poziom ich rozwoju. Jego przyspieszenie, szczególnie w okresie ostatnich dziesięciu lat, w części małych państw wyspiarskich, przy jednoczesnej stagnacji innych, skłania do ich ponownej klasyfikacji. Odwołanie się do wypracowanych i powszechnie akceptowanych w literaturze przedmiotu modeli rozwojowych SIDS (MIRAB, SITE i PROFIT) wraz z przyporządkowaniem ich do konkretnego państwa, stało się pretekstem do próby odpowiedzi na pytanie - która ze strategii gospodarczej, wynikającej z danego modelu, przyczyniła się do podniesienia poziomu - nie tylko do wzrostu, ale szeroko rozumianego rozwoju społeczno-gospodarczego w małych państwach wyspiarskich.

${ }^{1}$ Cechę tę literatura anglojęzyczna określa jako vulnerability - co tłumaczyć można jako podatność gospodarki na zranienia (ciosy), niezabezpieczoną przed atakami (ciosami), posiadającą słabe (niezabezpieczone) punkty. Termin ten powszechnie stosowany jest m.in. przez Konferencję Narodów Zjednoczonych ds. Handlu i Rozwoju (UNCTAD). 
Na potrzeby artykułu autor odwoła się do klasyfikacji (UNCTAD, 2010, s. 5), która za SIDS przyjmuje 29 niezależnych państw: 13 położonych na Oceanii (Federacyjne Stany Mikronezji, Fidżi, Kiribati, Nauru, Palau, Papua Nowa Gwinea, Samoa, Timor Wschodni, Tuvalu, Vanuatu, Wyspy Marshalla, Wyspy Salomona oraz Wyspy Tonga); 10 karaibskich (Antigua i Barbuda, Bahamy, Barbados, Dominika, Grenada, Jamajka, Saint Kitts i Nevis, Saint Lucia, Saint Vincent i Grenadyny oraz Trynidad i Tobago); 2 położone na Atlantyku Wschodnim (Republika Zielonego Przylądka oraz Wyspy Świętego Tomasza i Książęca) oraz 4 na Oceanie Indyjskim (Malediwy, Mauritius, Seszele oraz Związek Komorów)².

\section{Paradygmat trzech modeli rozwoju gospodarczego małych państw wyspiarskich}

W literaturze z zakresu Island Economics wyróżniono trzy podstawowe modele strategii rozwojowych małych państw wyspiarskich: MIRAB, SITE i PROFIT. Pierwszy - MIRAB - akronim od: Mi - migration (migracje), $\mathrm{R}$ - remittances (przekazy), A - aid (pomoc), B - bureaucracy (biurokracja), w obrazowy sposób ukazuje zasadę funkcjonowania takiej gospodarki. Dominującymi źródłami gospodarowania są dwa elementy. Pierwszym jest migracja zarobkowa znacznej części mieszkańców wysp do państw o dużo wyższym poziomie rozwoju gospodarczego i przesyłanie (przekazy) nabytych środków finansowych (czy też rzeczowych). Drugim jest otrzymywanie pomocy rozwojowej, do której (wraz z jej wzrostem), potrzebna jest coraz większa liczba urzędników do jej wdrażania (rozrost biurokracji) (Bertram, Watters, 1984, 1985, 1986; Bertram, 2006). Tym dwóm głównym elementom towarzyszą również inne - tzw. nowe źródła dochodów - m.in. sprzedaż praw strategicznych, sprzedaż praw do zatapiania odpadów, handel narkotykami, hazard, sprzedaż „symboli suwerenności”, sprzedaż paszportów (obywatelstwa), sprzedaż „listów gwarancyjnych”, rejestracja „tanich bander” oraz transmisja danych i obsługa informatyczna (Crocombe, 2001, s. 362-379; Jędrusik, 2005, s. 151-154). Drugi

${ }^{2}$ Klasyfikacja ta budzi wiele kontrowersji (por. Encontre, 2004; Hein, 2004). Wątpliwości budzi m.in. zaklasyfikowanie wysp „średnich” (Trynidad i Tobago, Mauritius, Republika Zielonego Przylądka, Samoa oraz Związek Komorów), „dużych” (Bahamy, Fidżi, Jamajka, Timor Wschodni, Vanuatu oraz Wyspy Salomona) oraz „bardzo dużych” (Papua Nowa Gwinea) - por. tab. 1, kolumny: C, D. 
z modeli - SITE - będącym akronimem od słów: małe (small), wyspiarskie (island), gospodarki turystyczne (tourist, economies) zakłada, że dominującym źródłem wpływów z zagranicy jest turystyka (McElroy, 2006; McElroy, Parry, 2010). W wyniku silnego zdominowania (podporządkowania) przez ten rodzaj działalności całej gospodarki wyspiarskiej zjawisko to określane jest również „monokulturą turystyczną" (Giezgała, 1969, s. 266, 371, 1977, s. 343-345; Wodejko, 1998, s. 140, 141; Jasiński, 2006; Kachniewska, Niezgoda, Pawlicz, 2012, s. 215-219). Trzeci z modeli - PROFIT (akronim od: $\mathrm{P}$ - people consideration affecting citizenship, residence and employment rights, $\mathrm{R}$ - resources management, $\mathrm{O}$ - overseas engagement and international recognition, $\mathrm{FI}$ - finance, insurance and taxation, $\mathrm{T}$ - transportation) - sprowadza się w dużej mierze do zjawiska określanego w literaturze ekonomicznej wieloma terminami - oazą podatkową, rajem podatkowym, tax haven, offshore lub offshore financial center. Dominującą specjalizacją w tym modelu jest świadczenie usług bankowo-finansowych, którym towarzyszą, choć w mniejszym stopniu niż w przypadku modelu MIRAB - „nowe źródła dochodów” (Baldacchino, 2006).

Osiąganie korzyści finansowych przez małe państwa wyspiarskie z wielu źródeł powoduje występowanie modeli-hybryd. Najpowszechniej w literaturze przedmiotu przyjmuje się model PROFIT-SITE. Gospodarkę tego typu charakteryzuje silnie rozwinięta gospodarka turystyczna (,monokultura turystyczna”), której towarzyszy rozwinięty w stopniu zaawansowanym sektor bankowo-finansowy. W tym ujęciu przyjmuje się dwa modele rozwoju małych państw wyspiarskich: PROFIT-SITE i MIRAB (Oberst, McElroy, 2007).

Analizując zachowania gospodarcze małych państw wyspiarskich w ujęciu dynamicznym, zauważyć można, że przebiegają one dwutorowo. Pierwsze, rozwijając się ścieżką modelu MIRAB, zamykają się (zakleszczają się) w zjawisku „monokultury pomocowej” - pozostając w modelu MIRAB. Drugie, rozwijając się ścieżką SITE, albo zostają zamknięte w „monokulturze turystycznej” (w „czystym” modelu SITE) lub też po okresie fazy SITE, dodatkowo rozwijając sektor bankowo-finansowy, wchodzą w fazę modelu-hybrydy SITE/PROFIT, by ostatecznie przejść do modelu PROFIT. Małe państwa wyspiarskie zakleszczone w modelu MIRAB, rozwijając gospodarkę turystyczną, przejść mogą do modelu-hybrydy MIRAB/SITE, następnie do modelu SITE i zgodnie ze wcześniejszymi spostrzeżeniami - do modelu-hybrydy SITE/PROFIT i PROFIT. W tym ujęciu, niebędącym w sprzeczności do poprzedniego, modele-hybrydy MIRAB/SITE i SITE/PROFIT stanowią „fazy” 
przejściowe pomiędzy „czystymi” modelami MIRAB, SITE i PROFIT (Bertram, 2006; Bertram, Poirine, 2007; Jasiński, 2009, 2010, 2017). Występują również nieliczne przypadki gospodarek o cechach MIRAB/PROFIT (Bertram, Poirine, 2007; Baldacchino, Bertram, 2009).

\section{Klasyfikacje gospodarek małych państw wyspiarskich}

Kompilując dwie powszechnie akceptowane w literaturze przedmiotu klasyfikacje (Oberst, McElroy, 2007; Bertram, Poirine, 2007; Baldacchino, Bertram, 2009 - patrz: tab. 1, kolumny: E, F) oraz konfrontując je z nowszymi danymi statystycznymi (za 2013 r.) dotyczącymi wpływów z eksportu towarowego, turystyki, pomocy rozwojowej oraz przekazów z zagranicy (w odsetkach) w PKB (patrz: tab. 1, kolumny: G, H, I, J) należy generalnie podtrzymać zastosowany podział z obu klasyfikacji (w analizowanych 29 małych gospodarkach wyspiarskich), uwzględniając jednak pewne modyfikacje (rys. 1).

W przypadkach Palau, Dominiki, Republiki Zielonego Przylądka i Vanuatu, gospodarcze zachowania bliższe są modelowi MIRAB/SITE. Na Palau w 2013 roku dominującym wpływom z turystyki $(51,2 \% \mathrm{w}$ stosunku do PKB) towarzyszyły znaczne wpływy z pomocy rozwojowej (14,8\% w stosunku do PKB). W pozostałych 13 przypadkach zaklasyfikowanych (Oberst, McElroy, 2007) jako PROFIT-SITE, stanowiących przedmiot badania, wpływy z pomocy rozwojowej były szczątkowe w żadnym z przypadków wskaźnik nie był liczbą dwucyfrową (por. tab. 1, kolumny: I, J). Pomoc rozwojowa stanowi na Palau istotne źródło dochodu, w wyniku tego gospodarkę tę należy potraktować jako hybrydę MIRAB/SITE, co jest zgodne z klasyfikacją (Bertram, Poirine, 2007; Baldacchino, Bertram, 2009). Na Dominice zaklasyfikowanej w obu przypadkach jako MIRAB (o względnie niewysokim udziale pomocy rozwojowej i przekazom z zagranicy - łącznie 8,6\% w stosunku do PKB) towarzyszyły w 2013 roku znaczne wpływy z turystyki (20,1\%). Ten ostatni element składnia do uznania turystyki jako drugiego istotnego źródła dochodu, a w konsekwencji do zaklasyfikowania gospodarki Dominiki do „przejściowego” modelu MIRAB/SITE. W ostatnich dwóch przypadkach (Republika Zielonego Przylądka i Vanuatu) znacznym wpływom z pomocy gospodarczej i przekazom z zagranicy (łącznie 22,7\% w stosunku do PKB w pierwszym przypadku, 14,3\% na Vanuatu) towarzyszyły znaczne wpływy z turystyki (odpowiednio 28,3 i 39,2\% w stosunku 
do PKB), co również przemawia za uznaniem tych gospodarek za hybrydę MIRAB/ SITE (patrz: tab. 1, kolumny: H, I, J).

Rysunek 1. Dominujące modele rozwoju w małych państwach wyspiarskich na świecie

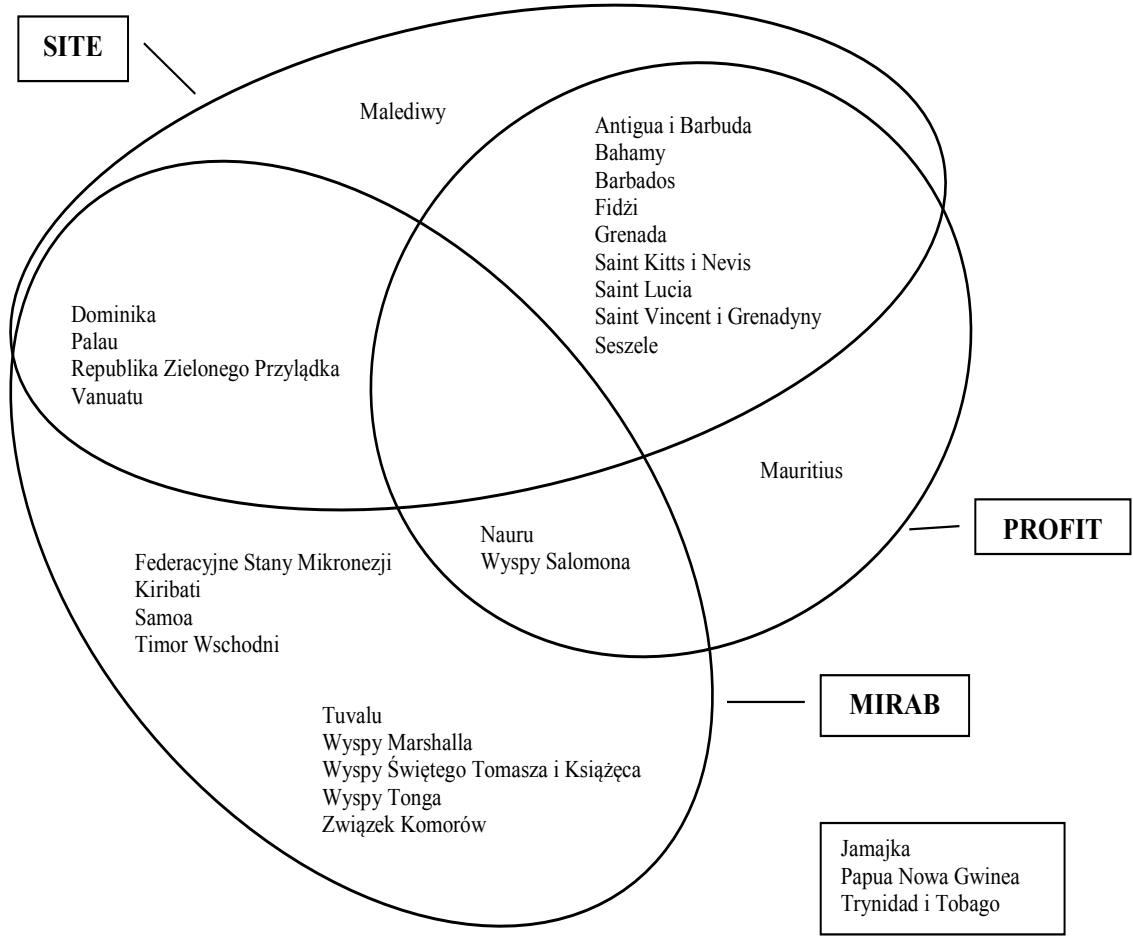

Źródło: na podstawie Oberst, McElroy (2007); Bertram, Poirine (2007); Baldacchino, Bertram (2009); Bank Światowy (2017).

Kolejne z państw - Malediwy - wydają się z perspektywy rozważań „wzorcowym” przykładem „,monokultury turystycznej” (modelu SITE). Zaklasyfikowanie gospodarki jako SITE/PROFIT (Bertram, Poirine, 2007; Baldacchino, Bertram, 2009) wydaje się być przedwczesne. W 2013 roku wskaźnik wpływów z turystyki w stosunku do PKB wynosił na Malediwach 83,6\%, co potwierdza tezę o silnie „monokulturowym” charakterze gospodarki turystycznej (patrz: tab. 1). Rozwój usług bankowo-finansowych, aby mówić o tym państwie jako o centrum bankowo-księgowym, (jeszcze) nie nastąpił. 
Odmienne przypadki stanowią Jamajka, Trynidad i Tobago oraz Papua Nowa Gwinea. Są to państwa, które nie posiadają typowych cech charakterystycznych dla żadnych z trzech analizowanych modeli. Gospodarki te charakteryzują się względną (jak na wyspiarskie standardy) różnorodnością (Jamajka) oraz dużym wskaźnikiem eksportu towarowego w PKB (Trynidad i Tobago, Papua Nowa Gwinea) (patrz: tab. 1, kolumna G). W wyniku niestwierdzenia cech dla analizowanych modeli, pozostaną one poza przyjętą na potrzeby artykułu klasyfikacją MIRAB, SITE i PROFIT (rys. 1).

\section{Zróżnicowanie poziomu rozwoju społecznego i zamożności w małych państwach wyspiarskich}

Specyfika SIDS (podobnie, jak pozostałych państw rozwijających się) skłania do alternatywnego podejścia do analizy działalności gospodarczej. Jest nim szeroko rozumiany rozwój społeczny - mieszczący w sobie pojęcia wzrostu i rozwoju gospodarczego (Bartkowiak, 2013, s. 59-65; Mirkowska-Ostatek, 2013, s. 49, 50). Perspektywa ta, wywodząca się od koncepcji A. Sena (Sen, 2002), znalazła uznanie $\mathrm{i}$ jest powszechnie akceptowana w literaturze przedmiotu. Metodą oceny efektywności tak pojmowanego gospodarowania jest wskaźnik rozwoju społecznego $(\mathrm{Hu}$ man Development Index - HDI).

Na podstawie analizy wskaźnika HDI dla 26 SIDS (na podstawie: Human Development Report, 2015 - patrz: tab. 1, kolumna: A) należy stwierdzić, że małe gospodarki wyspiarskie są bardzo zróżnicowane wewnętrznie pod względem poziomu rozwoju społecznego. Żadne z państw nie uzyskało bardzo wysokiego HDI (powyżej 0,800 ). W 17 poziom rozwoju społecznego jest jednak wysoki (przyjmując za graniczną wartość - średnią arytmetyczną HDI dla 188 państw w 2014 r. w wysokości 0,692 - patrz: rys. 2). W tej grupie wyraźne jest rozwarstwienie na trzy podgrupy. Państwa o najwyższym poziomie rozwoju - wskaźnik HDI w przedziale 0,790-0,772 (Bahamy, Barbados, Antigua i Barbuda, Palau, Mauritius, Seszele oraz Trinidad i Tobago), o średnim poziomie rozwoju - wskaźnik w granicach 0,752 (Saint Kitts i Nevis oraz Grenada) oraz niższym - wskaźnik w przedziale 0,7290,702 (Saint Lucia, Fidżi, Dominika, Saint Vincent i Grenadyny, Jamajka, Wyspy Tonga, Malediwy oraz Samoa). W przypadku państw o średnim i niskim poziomie rozwoju społecznego rozwarstwienie to jest jeszcze bardziej wyraźne. Do pierwszej 
grupy należy zaliczyć państwa o wskaźniku HDI zbliżonym do wartości 0,650 (Republika Zielonego Przylądka i Federacyjne Stany Mikronezji). Druga grupa to państwa o HDI zbliżonym do wartości 0,600 (Timor Wschodni, Vanuatu oraz Kiribati). Do trzeciej należy zakwalifikować Wyspy Św. Tomasza i Książęcą (wskaźnik 0,555). Ostatnia grupa to państwa o najniższym poziomie rozwoju - HDI niewiele powyżej 0,500 (Wyspy Salomona, Papua Nowa Gwinea oraz Związek Komorów) (patrz: rys. 2).

Przyjmując koncepcję wskaźnika HDI jako syntetycznej miary rozwoju społecznego, należy wyraźnie zaznaczyć, że występuje dodatnia zależność pomiędzy stopniem rozwoju a zamożnością. Wynika to m.in. z konstrukcji HDI, w przypadku którego jednym ze wskaźników cząstkowych jest poziom produktu na osobę, a poziomy pozostałych dwóch wskaźników cząstkowych zależą od zamożności społeczeństwa (Bartkowiak, 2013, s. 65; Human Development Report, 2015).

Analiza wskaźnika dochodu per capita (w PPP) wskazuje na duże dysproporcje pomiędzy dochodem na osobę w poszczególnych małych państwach wyspiarskich. Wśród 6 najzamożniejszych (granicę stanowi średnia arytmetyczna dla 188 państw wynosząca w 2014 r. 17015 USD - patrz rys. 2) dominuje Trinidad i Tobago, w przypadku którego wskaźnik przekroczył 25 tys. USD per capita. Następnie w przedziale pomiędzy 25 tys. a 20 tys. USD znajdują się 4 państwa (Seszele, Bahamy, Saint Kitts i Nevis, Antigua i Barbuda) oraz poniżej 20 tys. USD - Mauritius. Do grupy o niższym od przeciętnego dochodu na osobę (poniżej 17015 USD) - w przedziale od 15 do 10 tys. USD zaklasyfikować należy 4 państwa (Palau, Barbados, Malediwy oraz Grenadę). W przedziale od 10 tys. do 5 tys. USD 9 SIDS (Dominika, Saint Vincent i Grenadyny, Saint Lucia, Fidżi, Jamajka, Republika Zielonego Przylądka, Timor Wschodni, Samoa oraz Wyspy Tonga). Do państw najbiedniejszych - poniżej 5 tys. USD na osobę - pozostałe 8 (Wyspy Marshalla, Federacyjne Stany Mikronezji, Wyspy Świętego Tomasza i Książęca, Vanuatu, Papua Nowa Gwinea, Kiribati, Wyspy Salomona oraz Związek Komorów (patrz: tab. 1, kolumna B; rys. 2).

\section{Wybór strategii a obecny poziom rozwoju w małych gospodarkach wyspiarskich}

Wewnętrzne zróżnicowanie gospodarcze w małych gospodarkach wyspiarskich jest niewątpliwie efektem odmiennych przyrodniczych, historycznych 
i społecznych uwarunkowań, jak również nierównomiernego tempa włączania się w gospodarkę światową (Jędrusik, 2005, s. 143). Analiza zachowań gospodarczych po rozpadzie systemu kolonialnego wskazuje, że szczególnie decydujący o obecnym poziomie rozwoju społecznego w poszczególnych SIDS był fakt szybkiego i intensywnego włączenia w gospodarkę światową poprzez eksport usług turystycznych. W początkowej fazie na Karaibach (lata 50., 60., 70. XX w.), wraz z intensyfikacją tej specjalizacji - rozbudową infrastruktury turystycznej - dochodziło do „wypierania" (zgodnie z twierdzeniem Rybczyńskiego) tradycyjnych form gospodarowania („monokultura cukrowa”), a w konsekwencji do zjawiska „monokultury turystycznej” (,skrajnej” turystycznej choroby holenderskiej), czy ujmując z perspektywy rozważań - do gospodarowania w modelu SITE (Jasiński, 2006, 2009, 2010).

Rozwój infrastruktury turystycznej wraz z rozwojem infrastruktury transportowej (jak i wzrostem i rozwojem gospodarczym oraz „trwałym” rozwojem społecznym), w znacznej części wysp karaibskich umożliwił rozszerzenie działalności usługowej o usługi bankowo-finansowe (oazy podatkowe) - przejście do modelu PROFIT (Jędrusik, 2005, s. 154). W tej fazie (w latach 80. XX w.) czynniki te były niezbędne - „oazy” musiały dysponować dobrze rozwiniętą infrastrukturą komunikacyjną oraz wysoce wykwalifikowaną, władającą kilkoma językami kadrą (doradców biznesowych, księgowych, adwokatów, notariuszy itd.). Współcześnie cecha ta jest mniej pożądana, co wynika z możliwości ,wirtualnych” operacji finansowych. Ważną cechą pozostaje jednak posiadanie względnie liberalnego systemu prawnego oraz stabilnej sytuacji ekonomiczno-politycznej (Grzywacz, 2010, s. 59-62).

Spośród analizowanych 29 SIDS, jako pierwsze strategię SITE $\rightarrow$ SITE/PROFIT, stając się „modelowymi” dla pozostałych małych państw wyspiarskich, przyjęły karaibskie: Antigua i Barbuda, Bahamy oraz Barbados (Jasiński, 2009, 2010) współcześnie państwa o najwyższym poziomie rozwoju społecznego spośród SIDS na świecie (patrz: tab. 1, rys. 2).

Wyspy, które nie włączyły się w szerszym zakresie w początkowej fazie postkolonialnej w system gospodarki światowej (głównie wyspy pacyficzne, Oceanu Indyjskiego i Atlantyku Wschodniego), pozostały z fazie gospodarki tradycyjnej (rolnictwo, rybołówstwo, rzemieślnictwo), a następnie, wraz z rozrostem światowego systemu „pomocowego”, zostały „zamknięte” w „monokulturze pomocowej” $-\mathrm{w}$ modelu MIRAB. Pomoc rozwojowa dostarczana w długim okresie i znacznych sumach paradoksalnie spowodowała wolniejszy rozwój w tych państwach (Bertram, 


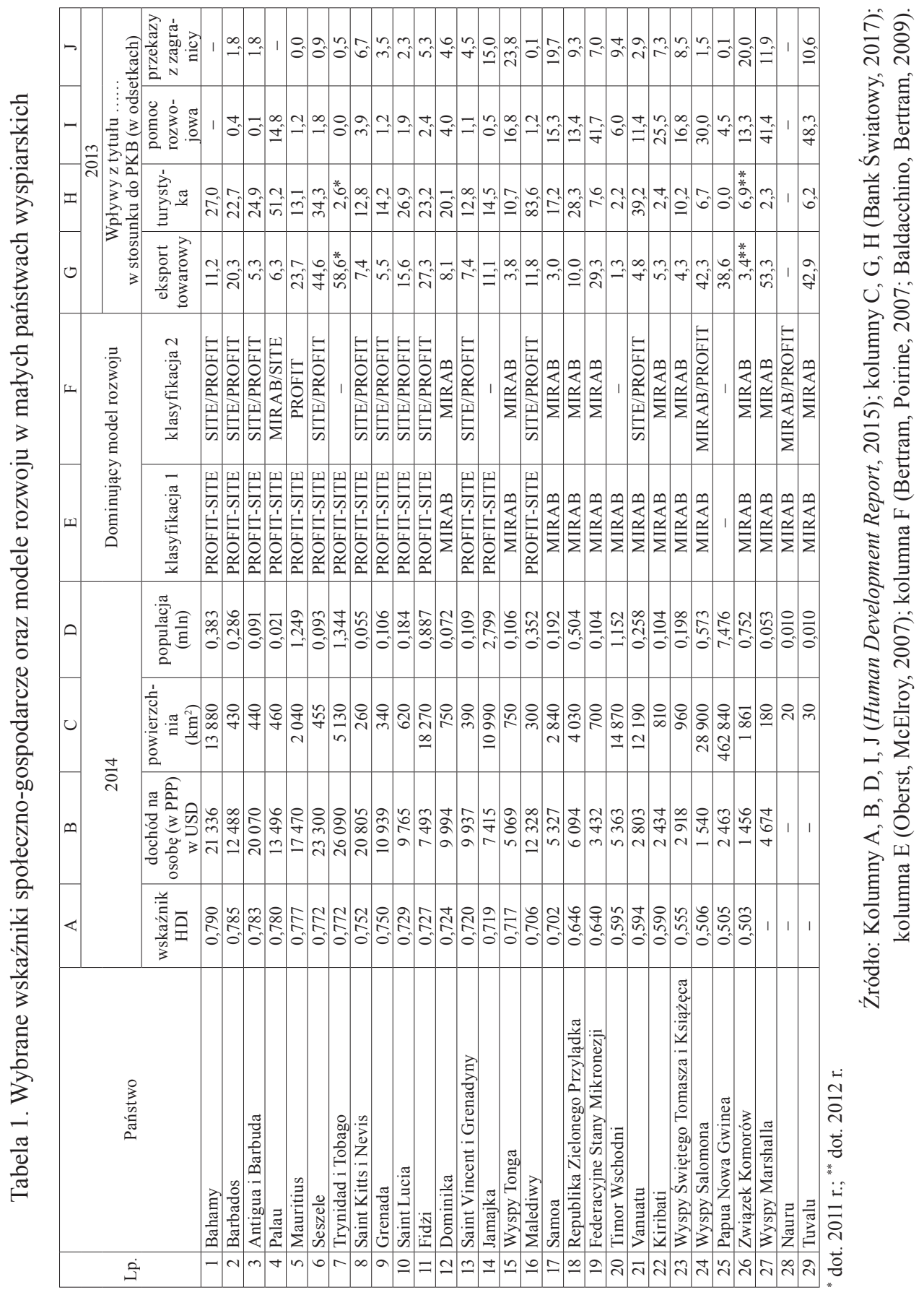


2013, s. 961, 962; Jasiński, 2017). Współcześnie małe gospodarki wyspiarskie gospodarujące według modelu MIRAB są najbiedniejszymi i najsłabiej rozwiniętymi spośród analizowanych SIDS (por. tab. 1, rys. 1, 2).

Rysunek 2. Dominujące modele gospodarowania a dochód na osobę (w USD) i wskaźnik rozwoju społecznego w 2014 roku w małych państwach wyspiarskich

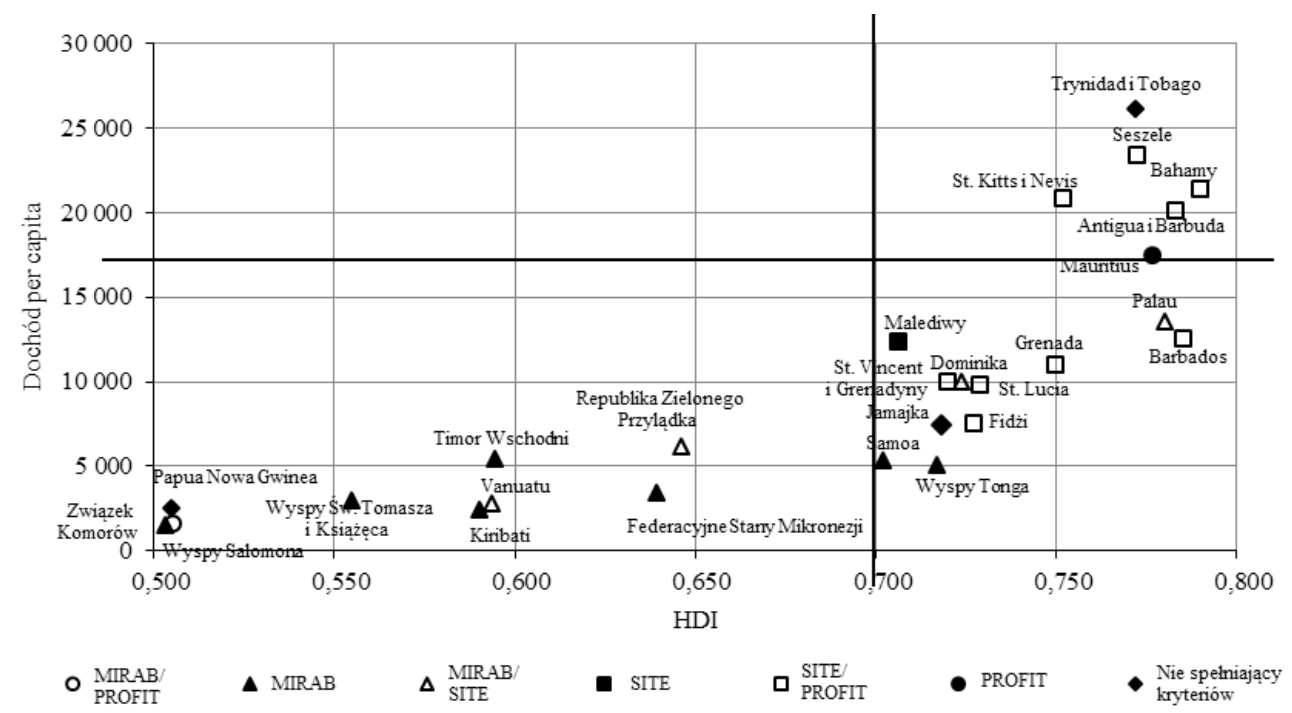

Źródło: na podstawie rys. 1; Human Development Report (2015)

Na dwóch skrajnych biegunach rozwoju (najbardziej rozwinięte - karaibskie: Antigua i Barbuda, Bahamy oraz Barbados $\leftrightarrow$ najmniej rozwinięte - pacyficzne: Timor Wschodni, Vanuatu, Kiribati, Wyspy Św. Salomona, Papua Nowa Gwinea, Wyspy Marshalla, Nauru oraz Vanuatu, na Ocenie Indyjskim: Związek Komorów oraz na Atlantyku Zachodnim: Wyspy Św. Tomasza i Książęca), należy umiejscowić państwa, które w późniejszych okresach fazy postkolonialnej włączały się intensywniej w nurty gospodarki światowej, zgodnie z naśladowanym schematem $\mathrm{SITE} \rightarrow$ SITE/PROFIT.

$\mathrm{W}$ dużym uproszczeniu za najistotniejsze $\mathrm{w}$ tym zagadnieniu wydaje się uwzględnienie trzech kwestii: (1) czasu (okresu), w którym zaczęto zmieniać orientację gospodarczą (kiedy nastąpił, zgodnie z koncepcją zależności od ścieżki, tzw. punkt zwrotny - por. Jasiński, 2009, 2010) i w wyniku, jaki okres czasu 
(jak długo) dana gospodarka funkcjonuje w tym modelu; (2) z jaką intensywnością rodzaj „,nowej” działalności (zgodnie z twierdzeniem Rybczyńskiego) „wyparł” inne formy gospodarowania - tzn. jak duży jest to sektor względem całej gospodarki oraz (3) sposób zarządzania całą gospodarką („kontrola nad nią”).

Zgodnie z wcześniejszymi uwagami - im wcześniej nastąpiła faza intensywnego włączenia w gospodarkę światową - tym wyższy poziom rozwoju i trwalsze efekty społeczno-ekonomiczne. Jakkolwiek widoczna w przypadku części SIDS jest również zasada, zgodnie z którą państwa doganiające rozwijają się szybciej niż prekursorzy (Landes, 2007, s. 311).

Palau (podobnie, jak inne pacyficzne małe państwa wyspiarskie) przez dziesięciolecia po II wojnie światowej pozostawała „odcięta od świata”. Najpóźniej ze wszystkich SIDS (w 1994 r.) uzyskała niepodległość (spod protektoratu Stanów Zjednoczonych Ameryki). Fakt pozostawania przez okres 50 lat (1945-1995) pod „opieką" amerykańską (w modelu MIRAB) oraz intensywniejsze włączenie się W turystyczną gospodarkę światową (konieczną ze względu na potrzebę zmiany orientacji gospodarczej - po uzyskaniu niepodległości) skutkuje przyspieszeniem rozwoju i obecnym jego poziomem (najwyższym spośród pacyficznych SIDS - por. rys. 1, 2, tab. 1).

Podobne spostrzeżenia dotyczyć mogą Samoa i Wysp Tonga, które pomimo zaklasyfikowania ich gospodarek jako MIRAB (por. rys. 1) osiągnęły (w 2013 r.) znaczące wpływy z turystyki (odpowiednio 17,2\% do PKB i 10,7\% do PKB), co „przekłada” się na wyższy poziom rozwoju. Wskazuje to na skuteczne pobudzenie rozwoju społecznego przez turystykę i stopniowe przechodzenie z modelu MIRAB do modelu MIRAB/SITE. Pomimo znacznych różnic poziomu rozwoju społecznego i zamożności pomiędzy Palau a Samoa i Wyspami Tonga, za szczególnie pozytywne należy odnotować (w ostatnich dwóch przypadkach) zjawisko względnie wysokiego (wyższego od przeciętnego) wskaźnika HDI (pomimo uzyskiwania niskiego dochodu per capita - por. rys. 2).

${ }^{3}$ Zgodnie z literaturą z zakresu Island economics rozwój gospodarczy małych państw wyspiarskich, a szczególnie (wyspiarskich) terytoriów zależnych, jest wprost proporcjonalny do siły politycznych związków tych obszarów z dawnymi i obecnymi metropoliami. Im zależność jest większa - tym poziom rozwoju wyższy. M.in. z tego wynika współczesna opieszałość w dążeniu do niepodległości licznych (zależnych) obszarów wyspiarskich na świecie (Armstrong, De Kervenoael, Li, Read, 1998; Armstrong, Read, 2000; Bertram, 2004; McElroy, Sanborn, 2005). 
Specyficzne szybkie przyspieszenie wzrostu gospodarczego (zapoczątkowane dzięki turystyce na początku lat 70. XX w.) nastąpiło na Malediwach. Państwo to jednak gospodarczo zostało zamknięte w silnej „monokulturze turystycznej” i za wyjątkiem rybołówstwa nie rozwija właściwie żadnej innej (poza turystyczną) działalności gospodarczej. Ponadto sam rodzaj prowadzonej polityki turystycznej jest krytykowany ze względu na jej formę. Rozwój gospodarki turystycznej na Malediwach przebiega bowiem według specyficznego modelu izolacji (Jędrusik, 2003) - charakteryzującego się m.in. brakiem udziału w zyskach z tego tytułu przez ludność lokalną. Odzwierciedleniem tego jest duża dysproporcja pomiędzy zamożnością a rozwojem społecznym na Malediwach (por. rys. 2). Tempo wzrostu gospodarczego nie „przekłada” się na poprawę standardów cywilizacyjnych i polepszenie bytu ludności - co stanowić powinno kwintesencję rozwoju w przypadku państw rozwijających się (Piasecki, 2003, s. 16). W wyniku tego na przykład UNCTAD (2010, s. 5) klasyfikuje Malediwy do grupy najbiedniejszych państw świata (wraz z innymi państwami wyspiarskimi, takimi jak: Kiribati, Samoa, Timorem Wschodnim, Tuvalu, Vanuatu, Wyspami Salomona, Wyspami Świętego Tomasza i Książęcą oraz Związkiem Komorów).

Odmienny od występującego na Malediwach wariant modelu SITE (czy też SITE/PROFIT) zaobserwować można na Seszelach i Mauritiusie, którego początki sięgają również początku lat 70 . XX wieku. W obu przypadkach gospodarka turystyczna rozwijana jest w specyficznej ,,równowadze”. Nie jest nastawiona na szybki ilościowy wzrost przyjazdowego ruchu turystycznego. Turystyka jest „wkomponowana" w całą gospodarkę (towarzyszą jej inne gałęzie, m.in. rolnictwo oraz przemysł przetwórczy - szczególnie w przypadku Mauritiusu). Taka polityka gospodarcza przynosi powolne (w porównaniu np. ze skokowym wzrostem Malediwów), ale długoterminowe korzyści ekonomiczne i społeczne (Jędrusik, 2005, s. 170, 189, 190). Odzwierciedlają to wskaźniki HDI, jak i zamożności (patrz tab. 1, rys. 2). Podobne wnioski co do ,wkomponowania” turystyki w inne rozwijane gałęzie gospodarcze można odnieść szczególnie do Barbadosu, jak i do Fidżi. W obu przypadkach odzwierciedleniem „zrównoważania gospodarczego” jest m.in. względnie niewysoki dochód per capita przy jednocześnie wysokim wskaźniku rozwoju społecznego (por. tab. 1, rys. 2). 


\section{Podsumowanie}

W literaturze Island economics wyróżniane są trzy podstawowe modele rozwoju małych państw wyspiarskich określone akronimami: MIRAB, SITE oraz PROFIT, jak również ich hybrydy. Na podstawie analizy charakterystycznych dla tych modeli cech dokonano klasyfikacji dla 29 SIDS. W jednym przypadku stwierdzono model PROFIT, w dziewięciu - SITE/PROFIT, w jednym - SITE, w czterech - MIRAB/SITE, w dziewięciu - MIRAB, w dwóch - MIRAB/SITE, w pozostałych trzech nie stwierdzono typowych cech charakterystycznych dla tych modeli.

Następnie, przy zastosowaniu wskaźnika HDI, jak i jego wskaźnika cząstkowego dochodu na osobę (w PPP, w USD), dokonano klasyfikacji analizowanych 29 małych państw wyspiarskich. Badanie potwierdziło, że w sześciu państwach wskaźnik rozwoju społecznego oraz dochód per capita jest wysoki (powyżej średniej światowej), w jedenastu rozwój społeczny jest wysoki, przy niższych od przeciętnych (światowych) dochodów w na osobę, w dziewięciu zaś zarówno poziom rozwoju, jak i dochodów jest niski, w tym w 3 przypadkach skrajnie niski. W dwóch przypadkach nie można było dokonać klasyfikacji z powodu braku danych, w jednym, w wyniku niepełnych danych, zaklasyfikowano je do państw o niskim dochodzie na osobę.

Niniejsze badania umożliwiły potwierdzenie postawionej tezy, która zakładała, że strategia gospodarowania, wynikająca z danego modelu, wpływa na obecny poziom rozwoju społeczno-gospodarczego. W przypadkach, gdy gospodarka małych państw wyspiarskich miała cechy modelu PROFIT, PROFIT/SITE lub SITE - rozwój ten był wyższy. W przypadku modelu MIRAB (oraz w modelu MIRAB/ PROFIT) w dominującej większości rozwój był bardzo niski. W przypadku modelu hybrydy MIRAB/SITE występującego w czterech państwach, w dwóch poziom rozwoju był wyższy od przeciętnego na świecie.

Dalsza analiza umożliwiła także wykazanie, że w sześciu małych państwach wyspiarskich rozwój sektora turystycznego (model SITE) spowodował w ostatnich dziesięcioleciach znaczne przyspieszenie rozwoju i dynamiczne „doganianie” najbardziej rozwiniętych małych gospodarek wyspiarskich. Potwierdziło to wcześniejsze badania autora (Jasiński, 2009, 2010), w tym szczególnie tezę, że rozwój sektora turystycznego (model SITE) stanowi niezbędną fazę pobudzenia rozwoju społeczno-gospodarczego w SIDS. Małe gospodarki wyspiarskie, nie mając innej 
możliwości rozwoju, muszą włączać się w nurt światowej gospodarki. Izolacja gospodarowanie w modelu MIRAB - jak wykazało badanie, rozwoju nie powoduje.

\section{Literatura}

Armstrong, H.W., De Kervenoael, R.J., Li, X., Read, R.A. (1998). Comparison of the Economic Performance of Different Micro-states, and Between Micro-states and Larger Countries. World Development, 26 (4), 639-656.

Armstrong, H.W., Read, R. (2000). Comparing the Economic Performance of Dependent Territories and Sovereign Microstates. University of Chicago.

Baldacchino, G. (2006). Managing the Hinterland beyond: Two Ideal-type Strategies of Economic Development for Small Island Territories. Asia Pacific Viewpoint, 47 (1), 45-60.

Baldacchino, G., Bertram, G. (2009). The Beak of the Finch: Insights into the Economic Development of Small Economies. The Round Table, 98 (401), 141-160.

Bank Światowy (2017). Pobrano z: http://data.worldbank.org (15.02.2017).

Bartkowiak, R. (2013). Ekonomia rozwoju. Warszawa: PWE.

Bertram, G., Watters, R.F. (1984). New Zealand and its Small Island Neighbours: A Review of New Zealand Policy Toward the Cook Islands, Niue, Tokelau, Kiribati and Tuvalu. Institute of Policy Studies, Victoria University of Wellington.

Bertram, G., Watters, R.F. (1985). The MIRAB Economy in South Pacific Microstates. Pacific Viewpoint, 26 (3), 497-519.

Bertram, G., Watters, R.F. (1986). The MIRAB Process: Earlier Analysis in Context. Pacific Viewpoint, 27 (1), 47-59.

Bertram, G. (2004). On the Convergence of Small Island Economies with Their Metropolitan Patrons. World Development, 32 (2), 343-364.

Bertram, G. (2006). Introduction: The MIRAB Model in the Twenty-first Century. Asia Pacific Viewpoint, 47 (1), 1-13.

Bertram, G. (2013). Pacific Island Economies. W: M. Rapaport (red.), The Pacific Islands: Environment and Society. The University of Hawai'i Press.

Bertram, G., Poirine, B. (2007). Island Political Economy. W: G. Baldacchino (red.), A World of Islands. Charlottetown: Institute of Island Studies, University of Prince Edward Island.

Crocombe, R. (2001). The South Pacific. Suva: University of South Pacific.

Encontre, P. (2004). SIDS as a Category: Adopting Criteria Would Enhance Credibility. W: Is a special treatment of small island developing States possible? UNCTAD.

Giezgała, J. $(1969,1977)$. Turystyka w gospodarce narodowej. Warszawa: PWE. 
Grzywacz, J. (2010). Pranie pieniędzy. Metody. Raje podatkowe. Zwalczanie. Warszawa: Oficyna Wydawnicza SGH.

Hein, P. (2004). Small Island Developing States: Origin of the Category and Definition Issues. W: Is a special treatment of small island developing States possible? UNCTAD.

Human Development Report (2015). UNDP.

Jasiński, M. (2006). Aspekty monokulturowe gospodarki turystycznej. Zeszyty Naukowe Kolegium Gospodarki Światowej, 20, 92-102.

Jasiński, M. (2009). Tourism and Small Island Developing States: Path Dependence, Lock in and History. W: Geography and Tourism: European Experience (s. 289-298). Lviv: Ivan Franko National University.

Jasiński, M. (2010). Teoria zależności od ścieżki a małe gospodarki wyspiarskie. Zeszyty Naukowe Kolegium Gospodarki Światowej, 28, 52-72.

Jasiński, M. (2017). Aspekty monokulturowe pomocowej choroby holenderskiej (w druku).

Jędrusik, M. (2003). Trzy modele kolonizacji turystycznej na przykładzie archipelagów mórz ciepłych. Przegląd Geograficzny, 1 (75), 81-100.

Jędrusik, M. (2005). Wyspy tropikalne. W poszukiwaniu dobrobytu. Warszawa: Wydawnictwa Uniwersytetu Warszawskiego.

Kachniewska, M., Niezgoda, A., Pawlicz, A. (2013). Globalizacja i internacjonalizacja działalności turystycznej. W: M. Kachniewska, E. Nawrocka, A. Niezgoda, A. Pawlicz (red.), Rynek turystyczny. Ekonomiczne zagadnienia turystyki. Warszawa: Oficyna a Wolters Kluwer business.

Landes, D.S. (2007). Bogactwo i nędza narodów. Dlaczego jedni sa tak bogaci, a inni tak ubodzy. Warszawa: MUZA SA.

McElroy, J.L. (2006). Small Island Tourist Economies across the Life Cycle. Asia Pacific Viewpoint, 47 (1), 61-77.

McElroy, J.L., Parry, C.E. (2010). The Characteristics of Small Island Tourist Economics. Tourism and Hospitality, 10, 315-328.

McElroy, J.L., Sanborn, K. (2005). The Propensity for Dependence in Small Caribbean and Pacific Islands. Bank of Valletta Review, 31, 1-16.

Mirkowska-Ostatek, M. (2012). Oficjalna pomoc rozwojowa jako czynnik eliminujący skalę ubóstwa w państwach Trzeciego Świata. W: E. Latoszek, M. Proczek (red.), Polityka rozwojowa. Rola organizacji międzynarodowych $w$ zwalczaniu ubóstwa na świecie. Warszawa: Oficyna Wydawnicza SGH.

Oberst, A. McElroy, J.L. (2007). Contrasting Socio-Economic and Demographic Profiles of Two, Small Island, Economic Species: MIRAB versus PROFIT/SITE. Island Studies Journal, 2 (2), 163-176. 
Piasecki, R. (2003). Rozwój gospodarczy a globalizacja. Warszawa: PWE.

Sen, A. (2002). Rozwój i wolność. Poznań: Zysk i S-ka.

UNCTAD (2010). In-depth eValuation of UNCTAD's Technical Cooperation Activities Dedicated to Least Developed Countries, Landlocked Developing Countries, Small Island Developing States and Other Structurally Weak, Vulnerable and Small Economies.

Wodejko, S. (1998). Ekonomiczne zagadnienia turystyki. Warszawa: Wyższa Szkoła Handlu i Prawa.

\title{
THE MODELS OF ECONOMIC DEVELOPMENT AND THE LEVEL OF HUMAN AND ECONOMIC DEVELOPMENT IN SMALL ISLAND DEVELOPING STATES
}

\begin{abstract}
The study presents small island developing states (SIDS) models of development: MIRAB, SITE, PROFIT and its correlation with level of socio-economic development in 29 small island economies. The SIDS taxonomy also shows the importance of SITE model.
\end{abstract}

Keywords: MIRAB, SITE, PROFIT, human development, small island economy

JEL codes: F63, F54, O1, O47 
